\section{Response of Creeping Bentgrass to Salinity and Mowing Management: Carbohydrate Availability and Ion Accumulation}

\author{
Y.L. Qian' ${ }^{1}$ and J.M. Fu \\ Department of Horticulture and Landscape Architecture, Colorado State \\ University, Fort Collins, CO 80523-1173
}

\begin{abstract}
Salt problems in turfgrass sites are becoming more common. The effects of mowing height on salinity tolerance and associated mechanisms are not well understood. The objective of this study was to examine the effects of mowing height and the level of salinity on turf quality, canopy photosynthetic rate (Pn), total nonstructure carbohydrate (TNC) content, shoot reducing sugar content (RSC), $\mathrm{Na}^{+}$and $\mathrm{K}^{+}$content in shoots and roots of creeping bentgrass (Agrostis palustris Huds.). Sod pieces of 'L-93' were grown in a greenhouse for over 7 months. Plants were subjected to three mowing heights: $6.4,12.7$, and $25.4 \mathrm{~mm}$, and to four salinity levels of irrigation water: control, $5 \mathrm{dS} \cdot \mathrm{m}^{-1}, 10 \mathrm{dS} \cdot \mathrm{m}^{-1}$, and $15 \mathrm{dS} \cdot \mathrm{m}^{-1}$ prepared using ocean salts. Increasing salinity resulted in reduced turf quality, increased shoot $\mathrm{Na}^{+}$, reduced $\mathrm{K}^{+}$, and reduced $\mathrm{K}$ to $\mathrm{Na}$ ratio, to a greater extent for bentgrass mowed at $6.4 \mathrm{~mm}$ mowing height. Reducing sugar content in shoot increased with increasing salinity level except at $15 \mathrm{dS} \cdot \mathrm{m}^{-1}$ and $6.4 \mathrm{~mm}$ mowing regime where RSC declined. Compared to the $25.4 \mathrm{~mm}$ mowing height, mowing height at $6.4 \mathrm{~mm}$ caused 32 $39 \%$ reduction in TNC, a $25 \%$ to $37 \%$ increase in $\mathrm{Na}^{+}$content, and $45 \%$ to $51 \%$ decrease in $\mathrm{K}$ content in shoots, which resulted in substantial decrease in $\mathrm{K} / \mathrm{Na}$ ratio. These results demonstrated that the reduction of creeping bentgrass salt tolerance under low mowing height was associated with carbohydrate depletion that reduced the plant's genetic abilities to generate osmo-protectants (such as reducing sugar), to reduce $\mathrm{Na}^{+}$accumulation in shoots, and to selectively uptake and transport $\mathrm{K}^{+}$. Therefore, a moderate increase in mowing height could improve salinity tolerance of creeping bentgrass.
\end{abstract}

Creeping bentgrass, because of its high turf quality, is one of the most widely used species on golf course putting greens, tees, and fairways in the temperate regions of the world. Golf course managers have been challenged to reduce mowing height to increase ball rolling distance and the quality of play surfaces. Creeping bentgrass is considered to have moderate salinity tolerance (Beard, 1973; Carrow and Duncan, 1998; Harivandi et al., 1992) and variations in salinity tolerance exist among different cultivars (Marcum, 2001). Previously it has been reported that the salinity damage of creeping bentgrass becomes more severe under close mowing conditions (Fu et al., 2005).

Salinity tolerance mechanisms of plants include salt exclusion, regulation of salt transport to shoots, salt secretion, synthesis of benign osmoprotectants, organismal and cellular salt compartmentations, and damage response and repair (Tester and Davenport, 2003). Many of the salt resistance mechanisms are energy dependent (Barrett-Lennard, 2003; Tester and Davenport, 2003). For example, sodium exclusion is in part associated with the ATPase activity in root cell membranes. For cellular salt compartmentation, the function of vascular $\mathrm{Na} / \mathrm{H}$ antiport relies on ATPase to

Received for publication 24 June 2005. Accepted for publication 11 July 2005. The research was supported by the O.J.Noer Research Foundation and the Colorado Agricultural Experimental Station (Project 780).

${ }^{1}$ Corresponding author; e-mail Yaling.Qian@colostate. edu. generate cytosol-directed electrochemical potential difference for $\mathrm{H}^{+}$across membrane. The syntheses of benign osmoprotectants rely on carbohydrate substances and energy (Rhodes et al., 2002). Soluble reducing sugars are thought to serve an important role in interacting with membrane phospholipids and proteins to stabilize their structures under salinity stress. Gram (1976) suggested that, of the various organic osmotica, sugars contribute up to $50 \%$ of the total osmotic potential in glycophytes subject to saline conditions.

Apositive balance of carbohydrate production and consumption would help plants maximize their ability to cope with salinity stress. Close mowing reduces canopy photosynthesis by removing large amounts of green leaves that otherwise are available for light interception (Hull, 1992), whereas nonphotosynthesizing tissues continue to respire or increase dark respiration (Krans and Beard, 1975), thereby reducing energy reserves and energy availability. Canopy photosynthesis and TNC in plants are physiological measures of energy production and energy availability under stressful conditions (Huang and Fu, 2000; Qian and Engelke, 1999; Qian et al., 1998).

The hypothesis of the current study is that the decline in bentgrass's ability to tolerate salinity under close mowing conditions is associated with the carbohydrate availability, the effectiveness of $\mathrm{Na}^{+}$exclusion from shoots, and the ability to selectivity uptake and transport $\mathrm{K}^{+}$. To test the hypothesis, the experiment was conducted to determine turf quality, canopy photosynthetic rate, total non-structure carbohydrate content (TNC), shoot reducing sugar content (RSC), $\mathrm{Na}^{+}$and $\mathrm{K}^{+}$content in shoots and roots under several combinations of mowing regimes and salinity levels.

\section{Materials and Methods}

Plant materials and growth conditions. Sod pieces (10 cm in diameter) of 'L-93' were collected from a U.S. Golf Association putting green seeded 4 years ago at the Horticulture Research Center, Fort Collins, Colo. After removing soil through hand washing, sod pieces were transplanted to polyvinyl chloride (PVC) tubes $(45 \mathrm{~cm}$ long and $10 \mathrm{~cm}$ in diameter) filled with sandy clay loam soil (Aridic Argiustoll) and kept in a greenhouse. A 10-cm-inside diameter PVC cap with five 1-cm-diameter holes drilled at the bottom was positioned at the bottom of the PVC tube for drainage. The soil $\mathrm{pH}$ and EC were 7.4 and 1.2 $\mathrm{dS} \cdot \mathrm{m}^{-1}$, respectively. Soil columns were packed to a bulk density of about $1.3 \mathrm{~g} \cdot \mathrm{cm}^{-3}$.

Plants were grown in the PVC tubes for 3 months, allowing root and canopy to establish before treatments were imposed. During this period, plants were watered on alternate days using tap water $\left(\mathrm{EC}=0.2 \mathrm{dS} \cdot \mathrm{m}^{-1}\right)$ until water drained freely from the holes at the bottom of each tube and fertilized weekly with Peters Excel solution(15N-2P-12K, Scotts-Sierra Horticultural Products Company Marysville, Ohio) to provide $24 \mathrm{~kg} \mathrm{~N} /$ ha per month. Turfgrass was hand clipped every $2 \mathrm{~d}$ at $6.4 \mathrm{~mm}$. The daytime greenhouse temperature ranged from 19.5 to $28.5^{\circ} \mathrm{C}$ and nighttime temperature ranged from 13.5 to $20.5^{\circ} \mathrm{C}$. Ambient photosynthetically active radiation just above the turf canopy at 10:00 $\mathrm{h}$ averaged about $1000 \mu \mathrm{mol} \cdot \mathrm{m}^{-2} \cdot \mathrm{s}^{-1}$.

Treatments. Salinity treatments were applied by irrigating with different concentrations of saline water. Irrigation waters of different salinity levels were prepared by the addition of ocean salts (Aquarium Syst., Mentor, Ohio) to tap water to obtain EC values of 5.0, 10.0, and $15.0 \mathrm{dS} \cdot \mathrm{m}^{-1}$. The tap water without addition of sea salts is used as the control (EC $\left.=0.2 \mathrm{dS} \cdot \mathrm{m}^{-1}\right)$. Concurrent to the initiation of salinity treatments, mowing treatments (that included clipping three times weekly at 25.4 $\mathrm{mm}$, four times at $12.7 \mathrm{~mm}$, and daily at 6.4 $\mathrm{mm}$ ) started. The irrigation waters were applied every $2 \mathrm{~d}$ with the amount equal to $120 \%$ of evapotranspiration (ET) measured with an extra PVC container (served as a lysimeter) of bentgrass mowed at $25.4 \mathrm{~mm}$. The amount of water applied was the same for all salinity and mowing treatments. Salinity and mowing treatments continued for 4 months.

Measurements. Data were collected for turf quality, Pn, soil salinity, shoot TNC, shoot $\mathrm{RSC}$, and tissue $\mathrm{Na}^{+}$and $\mathrm{K}^{+}$content for each treatment.

Visual turf quality was rated biweekly based on color, density, and uniformity using a scale of 0 (brown, dead turf) to 9 (optimum color, dense, and uniform turf), with a rating of 6.0 or higher indicating acceptable quality.

Canopy net photosynthetic rate was measured biweekly between 10:00 and 15:00 HR 
Table 1. Analysis of variance of turf quality, total non-structure carbohydrate content (TNC), shoot reducing sugar content (RSC), shoot Na ${ }^{+}$and $\mathrm{K}^{+}$content, canopy photosynthetic rate $(\mathrm{Pn})$, and soil salinity with mean squares and treatment significance levels.

\begin{tabular}{|c|c|c|c|c|c|}
\hline \multirow[b]{2}{*}{ Variable } & \multicolumn{5}{|c|}{ Mean square } \\
\hline & Mowing ht & Block & Mowing ht $\times$ block & Salinity level & Mowing regime $\times$ salinity \\
\hline Turf quality & $7.5^{*}$ & 0.1 & 0.7 & $67.8^{* * * * *}$ & $3.4^{*}$ \\
\hline $\mathrm{TNC}$ & $9243^{* * * *}$ & $301^{*}$ & $283^{*}$ & $815^{* * *}$ & $392^{* *}$ \\
\hline $\mathrm{RSC}$ & $2922^{* * * * *}$ & $15.8^{*}$ & $23.2^{*}$ & $108^{* *}$ & $77^{*}$ \\
\hline Root $\mathrm{Na}^{+}$content $\left(\mathrm{mg} \cdot \mathrm{kg}^{-1}\right)$ & $2.5 \times 10^{4}$ & $25 \times 10^{4^{*}}$ & $6.2 \times 10^{4}$ & $58 \times 10^{4^{* * * *}}$ & $8.5 \times 10^{4}$ \\
\hline Root $\mathrm{K}^{+}$content $\left(\mathrm{mg} \cdot \mathrm{kg}^{-1}\right)$ & $7.0 \times 10^{4}$ & $8.9 \times 10^{4 *}$ & $1.5 \times 10^{4}$ & $46 \times 10^{4^{* * * * *}}$ & $9.4 \times 10^{4 * *}$ \\
\hline Shoot $\mathrm{Na}^{+}$content $\left(\mathrm{mg} \cdot \mathrm{kg}^{-1}\right)$ & $56.7 \times 10^{6^{*}}$ & $4.3 \times 10^{6}$ & $6.6 \times 10^{6}$ & $403.4 \times 10^{6 * * * *}$ & $11.3^{*}$ \\
\hline Shoot $\mathrm{K}^{+}$content $\left(\mathrm{mg} \cdot \mathrm{kg}^{-1}\right)$ & $142.8 \times 10^{6 * * * *}$ & $9.8 \times 10^{6 * * *}$ & $0.73 \times 10^{6}$ & $174 \times 10^{6 * * *}$ & 1.35 \\
\hline $\mathrm{Pn}$ & $19.7^{* *}$ & 1.0 & $2.2^{* * *}$ & $78.4^{* * * * *}$ & 0.5 \\
\hline Soil salinity & $23.0^{* *}$ & 0.02 & 1.04 & $415.7^{* * * * *}$ & $2.16^{* * *}$ \\
\hline
\end{tabular}

${ }_{*, * * * * * * * * * * *}$ Significant level at $P \leq 0.05,0.01,0.001$, or $<0.0001$, respectively.

with a portable $\mathrm{CO}_{2}$ gas analyzer system (model CI-301; QC CID, Inc., Vancouver, Wash.). During each measurement, the whole turf canopy of individual PVC columns was enclosed in a transparent plexiglass chamber $(7.6 \mathrm{~cm}$ in height and $10 \mathrm{~cm}$ in diameter) for $2 \mathrm{~min}$. The canopy chamber was attached to the $\mathrm{CO}_{2}$ gas analyzer system to determine $\mathrm{CO}_{2}$ uptake. Canopy net photosynthetic rate was expressed as $\mathrm{CO}_{2}$ uptake per unit canopy area.

Soil salinity, $\mathrm{TNC}, \mathrm{RSC}$, and tissue $\mathrm{Na}^{+}$and $\mathrm{K}^{+}$content were determined at the termination of the experiment. To determine soil salinity, the PVC tubes containing soil were cut into four 10-cm-deep sections. One fourth of the soil within each section was air-dried for the measurement of soil salinity (and the rest of the soil was used to collect roots). The airdried soil was well mixed, crushed and passed through a 2-mm soil sieve. Deionized water was added to ground and sieved soil and mixed uniformly until a saturated paste was obtained. Electrical conductivity of saturation extract was determined with soil salinity appraisal kit (model CO150; Hach, Loveland, Colo.). Detailed information on salinity and root mass at different depths was presented in $\mathrm{Fu}$ et al. (2005). Data on average soil salinity over four depths was used in the current paper.

At the termination of the experiment, aboveground tissues (including shoots and stolons) were harvested and washed with cold water to remove plant debris for carbohydrate analysis. The samples were freeze-dried (Genesis 25 LL lyophilizer; Virtis, Gardiner, N.Y.). After freeze-drying, samples were ground with a Wiley mill, sieved thought a screen with $425-\mu \mathrm{m}$ openings, and kept in airtight vials at $-20{ }^{\circ} \mathrm{C}$. Total nonstructural carbohydrate content was measured using the method described by Chatterton et al. (1987). Briefly, 25 mg freeze-dried samples were transferred to 5 $\mathrm{mL} 0.1 \%$ clarase solution and incubated at 38 ${ }^{\circ} \mathrm{C}$ for $24 \mathrm{~h}$. Then $0.5 \mathrm{~mL}$ of hydrochloric acid ( $50 \%$, by volume) was added to the incubation solution. After the solution was incubated at room temperature for $18 \mathrm{~h}$, the $\mathrm{pH}$ value of the solution was adjusted to between 5 and 7 with 10 and $1 \mathrm{~N} \mathrm{NaOH}$. This solution was used to determine TNC content (the reducing sugar in the solution was considered as TNC content) using a spectrophotometer at $515 \mathrm{~nm}$ wavelength (model DU640; Beckman).

To measure free reducing sugar, $25 \mathrm{mg}$ of the freeze-dried, ground, and sieved sample was extracted with $10 \mathrm{~mL} 0.1 \mathrm{M}$ phosphate buffer $(\mathrm{pH}=5.4)$ for $24 \mathrm{~h}$ at room temperature.
Aliquot of extraction $(0.2 \mathrm{~mL})$ was used to determine the reducing sugar content by using method of measuring TNC.

To measure ion content, shoots and roots were harvested, washed with deionized water, and dried at $70{ }^{\circ} \mathrm{C}$ for $24 \mathrm{~h}$. Dried shoots and roots were ground in a Wiley mill to pass through a screen with $425-\mu$ m openings. About $1 \mathrm{~g}$ of screened and dried sample was weighed and ashed for $7 \mathrm{~h}$ at $500^{\circ} \mathrm{C}$. Ash was dissolved in $10 \mathrm{~mL}$ of $1 \mathrm{~N} \mathrm{HCl}$ and diluted with deionized water. Solution aliquots were analyzed for $\mathrm{Na}^{+}$ and $\mathrm{K}^{+}$by inductively coupled plasma atomic emission spectrophotometry (ICP-AES) (model 975 plasmaAtomcomp; Thermo Jarrell Ash Corp., Franklin, Mass.).

Statistical analysis. Asplit-plot experimental design was used with mowing regimes being the main plot treatments, and salinity levels of irrigation water being the subplot treatments. Each treatment had four replications. Effects of mowing, salinity, and their interaction were determined using analysis of variance according to the general linear procedure of the Statistical Analysis System (SAS, 2001) (Table 1). Because of a significant mowing regime and salinity level interaction on most of the measured variables, comparisons among mowing regimes within each salinity level were presented and means were separated by least significant difference at the 0.05 level of probability. Linear regression analysis was performed to determine the relationship between the measured parameters and soil salinity, where salinity level was the independent variable and each measured parameter was the dependent variable. Since turf quality and Pn measurements were taken on the same experimental units biweekly from week 10 to week 12 , a repeated measures analysis was performed to determine effects of mowing and salinity on turf quality and Pn (SAS, 2001).

\section{Results and Discussion}

Soil salinity and turf quality. A linear relationship of increasing soil salinity with increasing irrigation water salinity was observed for

Table 2. Influence of mowing height and irrigation water salinity on soil salinity.

\begin{tabular}{llccc}
\hline & \multicolumn{4}{c}{ Soil salinity $\left(\mathrm{dS} \cdot \mathrm{m}^{-1}\right)$} \\
\cline { 2 - 5 } Mowing ht & \multicolumn{4}{c}{ EC of irrigation water $\left(\mathrm{dS} \cdot \mathrm{m}^{-1}\right)$} \\
\cline { 2 - 4 }$(\mathrm{mm})$ & Check & 5 & 10 & 15 \\
\hline 6.4 & $1.04 \mathrm{~b}^{\mathrm{z}}$ & $6.04 \mathrm{c}$ & $10.73 \mathrm{c}$ & $15.23 \mathrm{~b}$ \\
12.7 & $1.03 \mathrm{~b}$ & $7.09 \mathrm{~b}$ & $12.61 \mathrm{~b}$ & $16.45 \mathrm{ab}$ \\
25.4 & $1.32 \mathrm{a}$ & $9.16 \mathrm{a}$ & $14.64 \mathrm{a}$ & $18.89 \mathrm{a}$ \\
\hline
\end{tabular}

${ }^{\mathrm{z}}$ Means in the same column followed by different letters are significantly different at $P=0.05$. each mowing regime $\left(R^{2}=0.92\right.$ to 0.99$)$ (Table 2). Since all treatments received the same amount of water, the $6.4 \mathrm{~mm}$ mowing regime exhibited lower soil salinity than the $25.4 \mathrm{~mm}$ mowing regime under all salinity treatments. At 5 and $10 \mathrm{dS} \cdot \mathrm{m}^{-1}$ salinity treatments, the $12.7 \mathrm{~mm}$ mowing regime exhibited lower soil salinity than the $25.4 \mathrm{~mm}$ mowing regime. Likely, the $6.4 \mathrm{~mm}$ mowing regime exhibited lower soil salinity than the $12.7 \mathrm{~mm}$ mowing regime. The trend of lower soil salinity with reduced mowing height was because a lower mowing height resulted in a higher leaching fraction; as we observed that greater volume of water was drained from the low mowing regimes. The higher leaching fractions from the low mowing treatments likely have occurred because turf mowed lower possessed lower ET rates.

Increasing soil salinity reduced turf quality, more severely and rapidly when mowed at 6.4 $\mathrm{mm}$ than at 12.7 or $25.4 \mathrm{~mm}$ (Fig. 1). Regression analysis of soil salinity and turf quality suggested that turf quality of creeping bentgrass mowed to $6.4,12.7$, and $25.4 \mathrm{~mm}$ fell to an unacceptable level when soil salinity reached $4.1,12.5$, and $13.9 \mathrm{dS} \cdot \mathrm{m}^{-1}$, respectively.

Canopy photosynthetic rate $(\mathrm{Pn})$. The interaction of salinity and mowing treatments on Pn was not significant (Table 1). Increasing salinity and reducing mowing height additively decreased canopy photosynthesis of creeping bentgrass (Table 3 ). As irrigation water salinity increased from control to $15 \mathrm{dS} \cdot \mathrm{m}^{-1}, \mathrm{Pn}$ reduced an average of $40 \%$. Although Pn is less sensitive to salinity compared to shoot growth (Fu et al., 2005), our results indicated that the reduction in Pn by close mowing (mowed to $6.4 \mathrm{~mm}$ ) and high salinity stress could lead to limited carbohydrate availability. The adverse effects of salinity on photosynthesis have been determined in studies in other species and creeping bentgrass (Balibrea et al., 2000; Chartzoulaki et al., 2002; Liu and Cooper, 2002). Using in a hydroponic system, Liu and Cooper (2002) reported that increasing salinity to $16 \mathrm{dS} \cdot \mathrm{m}^{-1}$ decreased net photosynthesis of to $16 \mathrm{dS} \cdot \mathrm{m}^{-1}$ decreased net photosynthesis of
creeping bentgrass by $20 \%$. In tomato plant, 


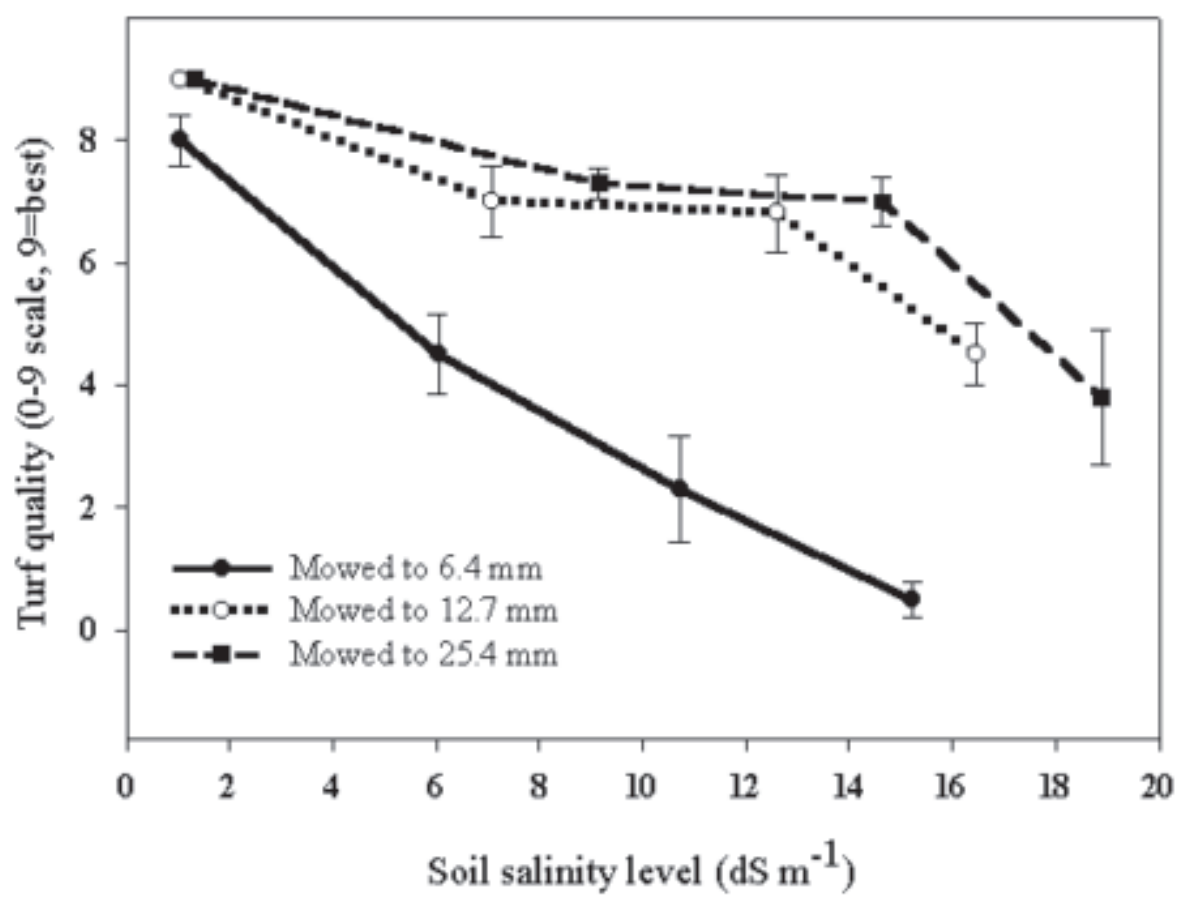

Fig. 1. Effects of soil salinity level on turf quality of creeping bentgrass at $6.4,12.7$, and $25.4 \mathrm{~mm}$ mowing heights. Bars represent standard error of the means. Turf quality was rated based on color, density, and uniformity using a scale of 0 (brown, dead turf) to 9 (optimum color, dense, and uniform turf).

Pn reduced $25 \%$ as $\mathrm{NaCl}$ concentration in a hydroponic solution increased from 0 to 100 mM (Balibrea, et al., 2000).

Carbohydrate availability in shoots. Interaction between salinity level of irrigation water and mowing treatments on TNC was significant(Table 1). Increasing irrigation water salinity from control to $15 \mathrm{dS} \cdot \mathrm{m}^{-1}$ decreased TNC by $15 \%$ and $28 \%$ under 12.7 and $6.4 \mathrm{~mm}$ mowing regime, respectively. Under $25.4 \mathrm{~mm}$ mowing regime, however, increasing salinity did not reduce shoot TNC (Table 4). Within each salinity treatment, total nonstructural carbohydrate content in shoots declined with reduced mowing height and increased mowing frequency, likely due to continued defoliation that removes photosynthetic tissues. However, high salinity escalated the TNC depletion caused by close mowing. Without salinity treatment, mowing height at $6.4 \mathrm{~mm}$ reduced TNC by $20 \%$ in comparison with turf mowed at $25.4 \mathrm{~mm}$. As salinity increased, the mowing effect became intensified. When irrigated with saline water at $15 \mathrm{dS} \cdot \mathrm{m}^{-1}$, mowing height at $6.4 \mathrm{~mm}$ reduced TNC by $39 \%$ in comparison with turf mowed at $25.4 \mathrm{~mm}$.

The reducing sugar in grass species mainly consists of glucose and fructose (Ball et al., 2002; Shahba et al., 2003). When mowed at 25.4 and $12.7 \mathrm{~mm}$, increasing salinity increased reducing sugar content in shoots of creeping bentgrass, despite a significant decrease in Pn (Table 4). Under $6.4 \mathrm{~mm}$ mowing height, however, increasing salinity to $15 \mathrm{dS} \cdot \mathrm{m}^{-1}$ reduced RSC at $P<0.1$.

Nonstructural carbohydrates are reserved energy sources in turfgrass plants. Soluble reducing sugars are thought to serve an important role in salinity, drought, and low temperature tolerance via osmotic adjustment and act as protectants as they prevent cell desiccation (Popp and Smirnoff, 1995). Soluble carbohydrates may interact with membrane phospholipids and proteins to stabilize their structures under salinity stress. Previous studies have demonstrated that salinity increases glucose and fructose content in olive (Olea europaea L.) (Gucci et al., 1998; Tattini, et al., 1996), wheat seedlings (Triticum aestivum L.) (Kerepesi and Galiba, 2000; Hu et al., 2000), and tomato (Lycopersicon esculentum L.) (Balibrea et al., 1996, 2000; Gao et al., 1998). Several studies have attempted to relate the magnitude of changes in soluble carbohydrate to salinity tolerance. Ashraf (1994) found that salt-tolerant wide populations of Melilotus indica and Eruca sativa had significantly higher soluble sugars in their leaves than the salt sensitive populations at varying salt levels of the growth medium.
A positive correlation $(r=0.71)$ between TNC and RSC in shoots suggests that TNC serves as the resources for the increased RSC under salinity conditions. Balibrea et al. (2000) reported that tomato plants growing under soil salinity stress had increased glucose and fructose content and decreased starch content. Downton (1977) found that grapevines (Vitis vinifera) exhibited increased reducing sugar content and reduced sucrose and starch under salinity stress. The lower TNC of plants under close mowing may predispose creeping bentgrass to salinity damage, partially because of the observed inability to accumulate reducing sugar as osmo-protectants.

Sodium exclusion from shoots and its breakdown with close mowing. In roots, only salinity significantly affected $\mathrm{Na}^{+}$content (Table 1). With increasing irrigation water salinity, $\mathrm{Na}^{+}$content increased (Table 5). Mowing height did not have a marked effect on root $\mathrm{Na}^{+}$content. However, salinity, mowing treatment, and salinity $\times$ mowing treatment interaction significantly affected root $\mathrm{K}$ content (Table 1). Bentgrass mowed to $6.4 \mathrm{~mm}$ exhibited the greatest reduction in $\mathrm{K}^{+}$content under salinity stress (Table 5). This trend was not significant when bentgrass was mowed at 12.7 and $25.4 \mathrm{~mm}$.

The interaction of salinity and mowing treatments was significant on shoot $\mathrm{Na}^{+}$content (Table 1). In shoots, $\mathrm{Na}^{+}$content increased with increasing soil salinity for all mowing regimes and the $\mathrm{Na}^{+}$accumulation slope with increasing soil salinity was higher for the 6.4 $\mathrm{mm}$ mowing regime than the 12.7 and 25.4 mm mowing regimes (Fig. 2). When grown at similar soil salinity levels, bentgrass mowed at $6.4 \mathrm{~mm}$ accumulated $42 \%$ to $59 \%$ higher sodium in shoots than bentgrass mowed at 12.7 and $25.4 \mathrm{~mm}$, respectively, (Fig. 2).

The interaction of salinity and mowing treatment was nonsignificant on shoot $\mathrm{K}^{+}$ content (Table 1). As irrigation water salinity increased from control to $5 \mathrm{dS} \cdot \mathrm{m}^{-1}$, shoot K content reduced $35 \%$ to $50 \%$. As salinity increased further, shoot K content did not show dramatic reduction. Across all salinity treatments, lower mowing height caused a decrease in shoot $\mathrm{K}$ content (Fig. 2). Bentgrass mowed at $6.4 \mathrm{~mm}$ had $32 \%$ to $40 \%$ and $45 \%$ to $51 \%$ lower shoot $\mathrm{K}$ content than at 12.7 and $24.5 \mathrm{~mm}$ mowing height, respectively.

It has been demonstrated that salinity tolerance in several grass species (Gramineae) is associated with exclusion of $\mathrm{Na}^{+}$from shoot and the capacity to maintain high shoot $\mathrm{K} / \mathrm{Na}$ (Qian et al., 2001; Qian et al, 2000; Torello and Rice, 1986). Reducing mowing height increased $\mathrm{Na}$ and reduced $\mathrm{K}$ content in shoots of bentgrass grown under salinity stress. The

Table 3. Canopy net photosynthesis $(\mathrm{Pn})$ response of creeping bentgrass to three mowing heights and four levels of saline irrigation water.

\begin{tabular}{|c|c|c|c|c|c|c|}
\hline \multirow{3}{*}{$\begin{array}{l}\text { Mowing } \\
(\mathrm{mm})\end{array}$} & \multicolumn{4}{|c|}{$\mathrm{Pn}\left(\mu \mathrm{mol} \mathrm{CO} / \mathrm{m}^{2} / \mathrm{s}\right)$} & \multirow{3}{*}{$\begin{array}{c}\text { Regression } \\
\text { (Pn vs. soil salinity) }\end{array}$} & \multirow[b]{3}{*}{$R^{2}$} \\
\hline & \multicolumn{4}{|c|}{ Salinity level of irrigation water $\left(\mathrm{dS} \cdot \mathrm{m}^{-1}\right)$} & & \\
\hline & Check & 5 & 10 & 15 & & \\
\hline 6.4 & $4.95 \mathrm{c}^{\mathrm{z}}$ & $3.88 \mathrm{c}$ & $3.61 \mathrm{c}$ & $2.02 \mathrm{~b}$ & $\mathrm{Y}=5.14-0.18 \mathrm{X}$ & $0.67^{* *}$ \\
\hline 12.7 & $5.90 \mathrm{~b}$ & $5.63 \mathrm{~b}$ & $4.81 \mathrm{~b}$ & $4.02 \mathrm{a}$ & $\mathrm{Y}=6.21-0.12 \mathrm{X}$ & $0.83^{* *}$ \\
\hline 25.4 & $7.47 \mathrm{a}$ & $6.57 \mathrm{a}$ & $6.08 \mathrm{a}$ & $4.53 \mathrm{a}$ & $Y=7.75-0.14 X$ & $0.65^{* *}$ \\
\hline
\end{tabular}

${ }^{2}$ Values followed by the same letters within a column are not significantly different $(P=0.05)$ based on a Fisher's LSD test.

${ }^{* *}$ Significant at $P \leq 0.01$ probability level. 
Table 4. Total nonstructural carbohydrates (TNC) and reducing sugar content (RSC) in shoots of creeping bentgrass subjected to three mowing heights and at four levels of irrigation salinity.

\begin{tabular}{|c|c|c|c|c|c|c|c|}
\hline \multirow{2}{*}{$\begin{array}{l}\text { Carbohydrate } \\
\text { type }\end{array}$} & \multirow{2}{*}{$\begin{array}{l}\text { Mowing } \\
\mathrm{ht}(\mathrm{mm})\end{array}$} & \multicolumn{4}{|c|}{ Salinity level $\left(\mathrm{dS} \cdot \mathrm{cm}^{-1}\right)$} & \multicolumn{2}{|l|}{ Regression } \\
\hline & & Check & 5 & 10 & 15 & (TNC or RSC vs. soil salinity) & $R^{2}$ \\
\hline \multirow{2}{*}{$\overline{\mathrm{TNC}}\left(\mathrm{mg} \cdot \mathrm{g}^{-1}\right.$ dry wt) } & 12.7 & $142.5 \mathrm{ab}$ & $145.5 \mathrm{a}$ & $137.3 \mathrm{a}$ & $120.5 \mathrm{~b}$ & $y=-1.34 x+148.9$ & $0.36^{*}$ \\
\hline & 25.4 & $157.2 \mathrm{a}$ & $150.5 \mathrm{a}$ & $152.2 \mathrm{a}$ & $145.6 \mathrm{a}$ & $y=-0.56 x+157.6$ & 0.06 \\
\hline \multirow{2}{*}{$\mathrm{RSC}\left(\mathrm{mg} \cdot \mathrm{g}^{-1}\right.$ dry wt) } & 12.7 & $41.5 \mathrm{a}$ & $48.8 \mathrm{a}$ & $52.2 \mathrm{a}$ & $48.5 \mathrm{a}$ & $y=0.52 x+42.9$ & $0.33^{*}$ \\
\hline & 25.4 & $44.8 \mathrm{a}$ & $51.9 \mathrm{a}$ & $55.5 \mathrm{a}$ & $57.6 \mathrm{a}$ & $y=0.73 x+44.4$ & $0.57^{* *}$ \\
\hline
\end{tabular}

${ }^{2}$ Values followed by the same letters within a column are not significantly different $(P=0.05)$ based on a LSD test.

${ }^{+, * * * *}$ Significant at $P \leq 0.1,0.05$, or 0.01 .

Table 5. Sodium and potassium content in roots of 'L-93' creeping bentgrass subjected to three mowing heights under different levels of salinity.

\begin{tabular}{|c|c|c|c|c|c|c|c|}
\hline \multirow[b]{2}{*}{ Ion } & \multirow{2}{*}{$\begin{array}{l}\text { Mowing } \\
\mathrm{ht}(\mathrm{mm})\end{array}$} & \multicolumn{4}{|c|}{ Salinity level $\left(\mathrm{dS} \cdot \mathrm{cm}^{-1}\right)$} & \multirow{2}{*}{$\begin{array}{c}\text { Regression } \\
\text { (Na or K vs. soil salinity) }\end{array}$} & \multirow[b]{2}{*}{$R^{2}$} \\
\hline & & Check & 5 & 10 & 15 & & \\
\hline$\overline{\mathrm{Na}}$ & 12.7 & $549.3 \mathrm{a}$ & $715.3 \mathrm{a}$ & $983.9 \mathrm{a}$ & $1205.8 \mathrm{a}$ & $Y=42.6 x+467.4$ & $0.43^{* *}$ \\
\hline \multirow{2}{*}{ K } & 12.7 & $614.07 \mathrm{a}$ & $258.54 \mathrm{~b}$ & $443.45 \mathrm{a}$ & $529.06 \mathrm{a}$ & $Y=-2.9 x+488$ & $0.01^{\mathrm{NS}}$ \\
\hline & 25.4 & $625.54 \mathrm{a}$ & $320.37 \mathrm{a}$ & $482.70 \mathrm{a}$ & $531.27 \mathrm{a}$ & $Y=-4 x+534.5$ & $0.02^{\mathrm{NS}}$ \\
\hline
\end{tabular}

${ }^{2}$ Values followed by the same letters within a column are not significantly different $(P=0.05)$ based on a LSD test.

NS, ${ }^{* *}$ Nonsignificant and significant regression (Na or $\mathrm{K}$ vs. soil salinity) at $P \leq 0.01$, respectively.
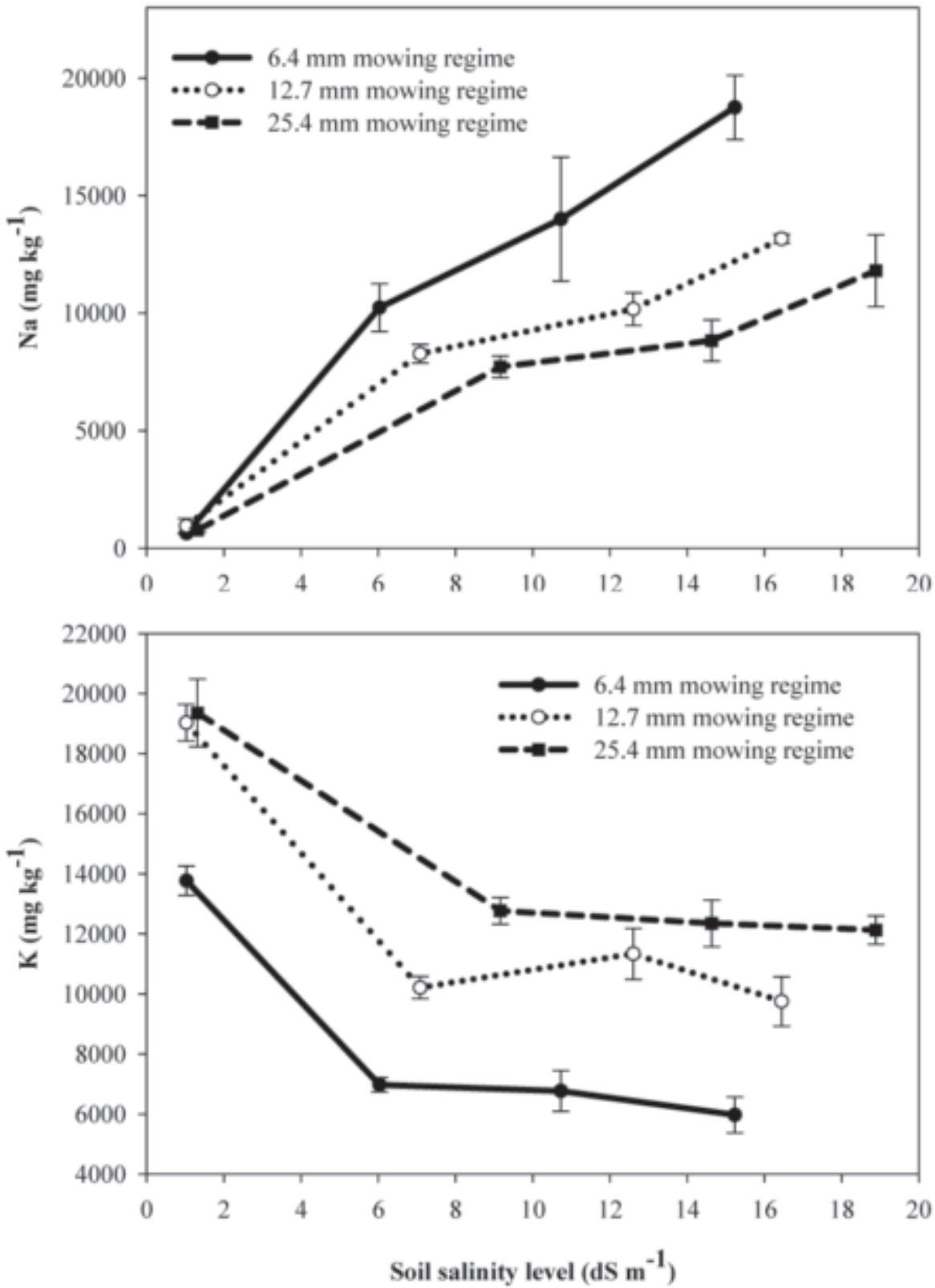

changes in $\mathrm{Na}^{+}$and $\mathrm{K}^{+}$resulted in a decrease in the $\mathrm{K}^{+}$to $\mathrm{Na}^{+}$ratio from 22 to $<1$. Wyn Jones et al. (1979) suggested a threshold $\mathrm{K}^{+}$ to $\mathrm{Na}^{+}$ratio of 1 for normal growth of plants subjected to salinity. Shannon (1978) studied salt tolerance of 32 lines of tall wheatgrass and found that salinity tolerance was associated with maintenance of $\mathrm{K}^{+}$to $\mathrm{Na}^{+}$ratio $>1$. Regression analysis predicted that shoot $\mathrm{K}^{+}$ to $\mathrm{Na}^{+}$ratio decreased to 1 at $6.0,7.1$, and 9.5 $\mathrm{dS} \cdot \mathrm{m}^{-1}$ when bentgrass was mowed to 6.4 , 12.7 , and $25.4 \mathrm{~mm}$, respectively.

Our data on $\mathrm{Na}$ and $\mathrm{K}$ content indicated that bentgrass had the highest selectivity of $\mathrm{K}^{+}$over $\mathrm{Na}^{+}$when maintain at $25.4 \mathrm{~mm}$ mowing height. Close mowing reduced the root selectivity for $\mathrm{K}$ under high salinity conditions and increased the uptake and transport of Na to shoots. Membrane proteins play a significant role in the selective distribution of ions within the plant and cell. These proteins include 1) primary $\mathrm{H}^{+}$-ATPases which generate the $\mathrm{H}^{+}$electrochemical gradient that drives ion transport through the plasma membrane with high selectivity for $\mathrm{K}$ over $\mathrm{Na}$, 2) $\mathrm{Na} / \mathrm{H}$ antiports in the plasma membrane for pumping excess $\mathrm{Na}$ out of the cell, 3) $\mathrm{Na} / \mathrm{H}$ antiports in the tonoplast for extruding $\mathrm{Na}$ into the vacuole (Ashraf and Harris, 2004; Tester and Davenport, 2003). All these are energy dependent processes. The selectivity of $\mathrm{K}$ over $\mathrm{Na}$ in the root uptake and transport are likely regulated to a substantial degree by $\mathrm{H}^{+}$ gradients across the plasma membrane. These $\mathrm{H}^{+}$gradients are maintained by $\mathrm{H}^{+}$-ATPase activity. Low mowing height depletes TNC reserves that induce ATP deficit, resulting in the lack of energy to power active ion selectivity in uptake and transport.

Our results on $\mathrm{Pn}, \mathrm{TNC}, \mathrm{RSC}$, and $\mathrm{Na}$ and $\mathrm{K}$ content support our hypothesis, i.e., salinity tolerance of creeping bentgrass is appreciably

Fig. 2. Effects of soil salinity on shoot foliage and stolon $\mathrm{Na}^{+}$and $\mathrm{K}^{+}$content of creeping bentgrass at 6.4, 12.7, and $25.4 \mathrm{~mm}$ mowing heights. Bars represent standard error of the means. 
lowered under close mowing conditions and this reduction is associated with reduced carbohydrate availability that leads to reduced ability to effectively produce osmo-protectants (such as glucose and fructose), minimize $\mathrm{Na}$ accumulation in shoots, and selectively uptake and transport $\mathrm{K}$.

\section{Literature Cited}

Ashraf, M. 1994. Genetic-variation for salinity tolerance in spring wheat. Hereditas 120:99-104.

Ashraf, M and P.J.C. Harris. 2004. Potential biochemical indicators of salinity tolerance in plants. Plant Sci. 166:3-16.

Balibrea, M.E., A.M.S. Cruz, M.C. Bolarin, and F. Perez-Alfocea. 1996. Sucrolytic activities in relation to sink strength and carbohydrate composition in tomato fruit growing under salinity. Plant Sci. 118:47-55.

Balibrea, M.E., J. Dell's Amico, M.C. Bolarín, and F. Pérez-Alfocea. 2000. Carbon partitioning and sucrose metabolism in tomato plants growing under salinity. Physiol. Plantarum 110:503-511.

Ball, S., Y.L. Qian, and C. Stushnoff. 2002. Soluble carbohydrates in two buffalograss cultivars with contrasting freezing tolerance. J. Amer. Soc. Hort. Sci. 127:45-49.

Barrett-Lennard,E.G. 2003. The interaction between waterlogging and salinity in higher plants: Causes, consequences and implications. Plant Soil 253:35-54.

Beard, J.B. 1973. Turfgrass: Science and culture. Prentice-Hall, Englewood Cliffs, N.J.

Carrow, R.N., and R.R. Duncan. 1998. Salt-affected Turfgrass Sites: Assessment and management. Ann Arbor Press. Chelsea, Mich.

Chartzoulaki, K., M. Loupassaki, M. Bertaki, and I. Androulakis. 2002. Effects of $\mathrm{NaCl}$ salinity on growth, ion content and $\mathrm{CO}_{2}$ assimilation rate of six olive cultivars. Scientia Hort. 96:235-247.

Chatterton, N.J., J.H. Bennett, and W.R. Thornley. 1987. Fructan, starch, and sucrose concentrations in crested wheatgrass and redtop as affected by temperature. Plant Physiol. Biochem. 25:617-623.

Downton, W.J.S. 1977. Photosynthesis in saltstressed grapevines. Austral. J. Plant Physiol. 4:183-192.

Fu, J., A.J. Koski, and Y.L. Qian. 2005. Responses of creeping bentgrass to salinity and mowing management: Growth and turf quality. Hort-
Science 40:463-467.

Gao, Z.F., M. Sagi. and S.H. Lips. 1998. Carbohydrate metabolism in leaves and assimilate partitioning in fruits of tomato (Lycopersicon esculentum L.) as affected by salinity. Plant Sci. 135:149-159.

Gram, W.J. 1976. Negative feedback regulation of transport in cells. The maintenance of turgor, volume and nutrient supply, p. 284-316. In: U. Luttge and M.G. Pitman (eds.). Encyclopaedia of Plant physiology. new ser. vol. 2. SpringerVerlag, Berlin.

Gucci, R., A. Moing. E. Gravano, and J.P. Gaudillere. 1998. Partitioning of photosynthetic carbohydrates in leaves of salt-stressed olive plants. Austral. J. Plant Physiol. 25:571-579.

Harivandi, M.A., J.D. Butler, and L.Wu. 1992. Salinity and turfgrass culture, p. 208-230. In: D.V. Waddington et al. (eds.). Turfgrass. Agron. Monogr. 32. ASA-CSSA-SSSA, Madison, Wis.

Huang, B. and J. Fu. 2000. Photosynthesis, respiration, and carbon allocation of two cool-season perennial grasses in response to surface soil drying. Plant Soil 227:17-26.

Hull, R. 1992. Energy relations and carbohydrate partitioning in turf grass, p.175-205. In: D.V. Waddington et al. (ed.). Turfgrass. Agron. Monogr. 32. ASA-CSSA-SSSA, Madison, Wis.

Hu, Y.C., H. Schnyder, and U. Schmidhalter. 2000. Carbohydrate deposition and partitioning in elongating leaves of wheat under saline soil conditions. Austral. J. Plant Physiol. 27:363-370.

Kerepesi, I. and G. Galiba. 2000. Osmotic and salt stress-induced alteration in soluble carbohydrate content in wheat seedlings. Crop Sci. 40:482-487.

Krans, J.V. and J.B. Beard. 1975. The Effect of clipping height and frequency on several physiological and morphological responses in 'Merion' kentucky bluegrass. Agron. Abstr. 67:100

Liu, C. and R.J. Cooper. 2002. Humic acid application does not improve salt tolerance of hydroponically grown creeping bentgrass. J. Amer. Soc. Hort. Sci. 127:219-223.

Marcum, K.B. 2001. Salinity tolerance of 35 bentgrass cultivars. HortScience. 36:374-376.

Popp, M. and N. Smirnoff. 1995. Polyol accumulation and metabolism during water deficit, p. 199-215. In: N. Smirnoff (ed.). Environment and plant metablolism: Flexibility and acclimation. Bios scientific, Oxford,
Qian, Y.L. and M.C. Engelke. 1999. Influence of trinexapac-ethyl on diamond zoysiagrass in a shade environment. Crop Sci. 39:202-208.

Qian, Y.L., M.C. Engelke, M.J.V. Foster, and S. Reynolds. 1998. Trinexapac-ethyl restricts shoot growth and improves quality of 'Diamond' zoysiagrass under shade. HortScience 33:1019-1022.

Qian, Y.L., M.C. Engelke, and M.J.V. Foster. 2000. Salinity effects on zoysiagrass cultivars and experimental lines. Crop Sci. 40:488-492.

Qian,Y.L., S.J. Wilhelm, and K.B. Marcum. 2001. Comparative responses of two kentucky bluegrass cultivars to salinity stress. Crop Sci. 41:1895-1900.

Rhoades, J.D. 1982. Soluble salts, p. 167-178. In: Page, A.L., R.H. Miller, and D.R. Keeney (eds.). Methods of soil analysis. Part 2. Chemical and microbiological properties. 2nd ed. ASA-SSSA-Madison, Wis.

Rhodes, D., A. Nadolska-Orczyk, and P.J. Rich. 2002. Salinity, osmolytes, and compatible solutes, p. 181-204. In: Läuchli and Lüttge (eds.). Salinity: Environment-plants-molecules. Kluwer Academic Publishers, Dordrecht, The Netherlands.

SAS Institute. 2001. SAS/STAT user's guide. SAS Inst., Cary, N.C.

Shahba, M. A., Y.L. Qian, H.G. Hughes, A.J. Koski, and D. Christensen. 2003. Relationship of carbohydrates and cold hardiness in six saltgrass accessions. Crop Sci. 43:2148-2153.

Shannon, M.C. 1978. Testing salt tolerance variability among tall wheatgrass lines. Agron. J. 70:719-722.

Tattini, M., R. Gucci, A. Romani, A. Baldi, and J.D. Everard. 1996. Changes in non-structural carbohydrates in olive (Olea europaea) leaves during root zone salinity stress. Physiol. Plantarum 98:117-124.

Tester, M. and R. Davenport. 2003. $\mathrm{Na}^{+}$tolerance and $\mathrm{Na}^{+}$transport in higher plants. Ann. Bot. 91:503-527.

Torello, W.A., and L.A. Rice. 1986. Effects of $\mathrm{NaCl}$ stress on proline and cation accumulation in salt sensitive and tolerant turfgrasses. Plant Soil 93:241-247.

Wyn Jones, R.G., C.J. Brady, and J. Speirs. 1979. Ionic and osmotic relations in plant cells, $\mathrm{p}$ 63-103. In: D.L. Laidman, and R.G. Wyn Jones (eds.). Recent advances in the biochemistry of cereals. Academic Press, London. 